\title{
EDITORIAL
}

\section{Impact factor and its role in academic promotion}

\author{
*Mark L Levy \\ On behalf of the editors of the \\ Primary Care Respiratory Journal \\ Senior Clinical Research Fellow, Allergy \\ \& Respiratory Research Group \\ Division of Community Health \\ Sciences:GP section, University of \\ Edinburgh, Scotland, UK; \\ Editor-in-Chief, Primary Care Respiratory \\ Journal \\ *Correspondence: \\ Dr ML Levy \\ c/o GPIAG, Smithy House, Waterbeck, \\ Lockerbie, DG11 3EY, UK. \\ Tel: +44 (0)1461 600639 \\ Fax: +44 (0)1461 207819 \\ E-mail: marklevy@animalswild.com
}

19th July 2009

\section{This statement was adopted unanimously at the May 17, 2009 meeting of the International Respiratory Journal Editors Roundtable.}

In our collective experience as editors of international peer-reviewed journals, we propose that the impact factor calculated for individual journals should not be used as a basis for evaluating the significance of an individual scientist's past performance or scientific potential. There are several reasons why one should not equate the impact factor of a journal in which the scientist publishes with the quality of the scientist's research. For example, as revealed by several recently-published analyses of the impact factor: $:^{1-6}$

- A journal's impact factor is determined by a decided minority of its published manuscripts. Thus, the impact factor correlates poorly with the citations of an individual manuscript.

- The impact factor does not consider the number of scientists actively producing research in a given specialty field. Indeed, some journals feel the need to serve constituencies with relatively small numbers of participants who continue to address important questions even though the number of scientists available for citations is limited.

- A journal's impact factor can be inflated by certain journal practices such as publication of many review articles.

- Impact factor measures only the frequency of citations which cannot be assumed always to equate with quality.

There are alternative, and we believe more valid, measures of the quality and impact of an individual scientist's published contributions. Firstly, a citation record for the individual candidate is readily available via several types of Internet search engines. Secondly, the time-honoured practice of soliciting evaluations concerning the significance of a candidate's work from scientific peers who are carefully selected to be both highly qualified as well as being at "arms-length" from the candidate should be rigorously applied.

\section{References}

1. Chew M, Villanueva EV, Van Der Weyden MB. Life and times of the impact factor: Retrospective analysis of trends for seven medical journals (1994-2005) and their Editors' views. J Roy Soc Med 2007;100:142-50. http://dx.doi.org/10.1258/jrsm.100.3.142

2. Ketcham CM, Crawford JM. The impact of review articles. Lab Investig 2007;87:1174-85. http://dx.doi.org/10.1038/labinvest.3700688

3. Ogden TL, Bartley DL. The ups and downs of journal impact factors. Ann Occup Hyg 2008;52:73-82. http://dx.doi.org/10.1093/annhyg/men002

4. Smith R. Beware the tyranny of impact factors. I Bone Joint Surg (Br) 2008;90-B:125-6. http://dx.doi.org/10.1302/0301-620X.90B2.20258

5. Szklo M. Impact factor: Good reasons for concern. Epidemiol 2008;19:369. http://dx.doi.org/10.1097/EDE.0b013e31816b6a7a

6. Wilcox AJ. Rise and fall of the Thomson impact factor. Epidemiol 2008;19:373. http://dx.doi.org/10.1097/EDE.0b013e31816a1293 